\title{
Crystal structure of lead dinickel iron tris(orthophosphate): $\mathrm{PbNi} 2 \mathrm{Fe}\left(\mathrm{PO}_{4}\right)_{3}$
}

\section{S. Ouaatta, E. Benhsina, J. Khmiyas, A. Assani, M. Saadi and L. El Ammari}

Laboratoire de Chimie Appliquée des Matériaux, Centre des Sciences des Matériaux, Faculty of Sciences, Mohammed V University in Rabat, Avenue Ibn Battouta,BP 1014, Rabat, Morocco

ouaattasaid@gmail.com

The new orthophosphate $\mathrm{PbNi}_{2} \mathrm{Fe}\left(\mathrm{PO}_{4}\right)_{3}$ have been synthesized by solid-state reaction route and characterized by $\mathrm{X}$-ray diffraction, scanning electron microscopy, Infrared and Raman spectroscopy.

The analysis by single crystal and powder X-ray diffraction techniques showed that this compound crystallizes in the orthorhombic system with Imma space group and unit cell parameters $a=10,415$ (3) $\AA$; $b=13,165$ (4) $\AA$; c = 6,536 (2) $\AA$; V = 896,15 (5) $\AA^{3} ; Z=4$.

The three-dimensional framework of the crystal structure is built up by $\left[\mathrm{PO}_{4}\right]$ tetrahedra, $\left[\mathrm{FeO}_{6}\right]$ octahedra and $\left[\mathrm{Ni}_{2} \mathrm{O}_{10}\right]$ dimers of edge-sharing octahedra, linked through common corners or edges. This structure comprises two types of layers stacked alternately along the [100] direction. The first layer is formed by edge sharing octahedra $\left(\left[\mathrm{Ni}_{2} \mathrm{O}_{10}\right]\right.$ dimer) linked to $\left[\mathrm{PO}_{4}\right]$ tetrahedra via common edges and vertices while the second layer is built up from a row of corner-sharing $\left[\mathrm{FeO}_{6}\right]$ octahedra and $\left[\mathrm{PO}_{4}\right]$ tetrahedra forming an infinite linear chain. The layers are held together through vertices of $\left[\mathrm{PO}_{4}\right]$ tetrahedra and $\left[\mathrm{FeO}_{6}\right]$ octahedra, leading to the appearance of two types of tunnels parallel to the $\mathrm{a}$ and $\mathrm{b}$-axis directions in which the $\mathrm{Pb}^{2+}$ cations are located.

The structure affiliation of the studied phosphate to that of $\alpha-\mathrm{CrPO}_{4}$ and its spectroscopic properties will be discussed.

Keywords: X-ray diffraction; crystal structure; solid-state reaction; phosphate; $\alpha-\mathrm{CrPO}_{4}$ 